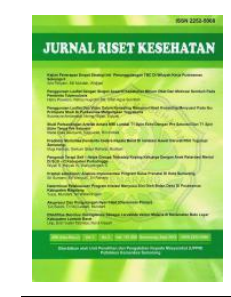

Jurnal Riset Kesehatan, 9 (1), 2020, 56 - 60

DOI: $10.31983 /$ jrk.v9i1.5695

Jurnal Riset Kesehatan

http://ejournal.poltekkes-smg.ac.id/ojs/index.php/jrk

\title{
THE ADOLESCENTS' CHARACTERISTICS WITH ANEMIA IN SENIOR HIGH SCHOOL MUALLIMAT YOGYAKARTA
}

\author{
Luluk Khusnul Dwihestie ${ }^{a^{*}}$; Luluk Rosidab \\ a,b Fakultas Ilmu Kesehatan Universitas 'Aisyiyah Yogyakarta ; \\ Jl. Siliwangi no.63; Yogyakarta 55592 ; Indonesia
}

\begin{abstract}
Anaemia is a global health problem. Anemia occurs more likely in women and adolescents. This is due to menstruation experienced every month which causes low levels of hemoglobin. Adolescence is a period of growth that requires more nutritional intake. Anemia in adolescent impacts on decreased of body immunity and the reduce of concentration. The purpose of this research is to find out the adolescents' characteristics with anemia in Senior High School Muallimat Yogyakarta. This research is descriptive analytic research with cross sectional approach, a population of 425 students of class $X, 40$ sample students, and a purposive sampling technique. The results show a description of the characteristics of adolescent in Senior High School Muallimat Yogyakarta which was that the majority of respondents aged 16 years of the 22 respondents $(63.0 \%)$; the majority of adolescents experienced menarche at age 12 as many as 12 respondents (30.0\%); adolescents having menstrual periods 1 time a month that a majority of 35 respondents $(87.5 \%)$. In addition, long menstrual majority in the normal category is 3-7 days as many as 29 respondents (72.5\%). It is expected that adolescents can consume vegetables and fruits containing iron, as well as Fe tablets during menstruation.
\end{abstract}

Keywords: Anemia, length of menstruation, menarche, menstrual cycle

\section{Introduction}

The prevalence of health problems in the community which is still quite high is anemia. The data from Riskesdas (2018) show that incidence of anemia in pregnant women reaches $48.9 \%$ of all ages. The biggest prevalence (84.6\%) is at the mother's age of 15-24 years. It is far from WHO standards for the prevalence rate of anemia in a region which must be below $20 \%$. In addition, WHO also expects that in 2025 the prevalence of anemia can be reduced by up to $50 \%$ (especially in women of childbearing age).

According to Budianto (2009), the prevalence of anemia can be used as an indicator to identify any deficiency of red blood cells that indicate the health status of the community. Anemia is determined by measuring the hemoglobin content in the blood. According to Yuni (2015), normal hemoglobin

*) Corresponding Author (Luluk Khusnul Dwihestie) E-mail: lulu.khusnul64@yahoo.com levels in men and women are different: male $13.5 \mathrm{gr} \%$ / dl and women $12 \mathrm{~g} \%$ / dl.

The cause of anemia is very varied, but half of which is supposed to be iron deficiency consumption. The research of Hapzah \& Yulita (2012) stated that the level of knowledge of adolescents doesn't influence healthy behavior because many teenagers do not like to eat fruit and vegetables containing iron, but they prefer foods that contain calories and low in fiber such as fast food. It's proven with their research showing that as many as 83 adolescents (74.8\%) preferred fast food.

The research of Gadjah Mada University (2018) found that approximately $12.8 \%$ of adolescents in Yogyakarta suffered from anemia. This assumed that 1 in 5 adolescents had anemia. The prevalence of anemia in an area is categorized as mild if there is less than $10 \%$ of the overall target, moderate category: $10-$ $39 \%$, and the category of distress $>39 \%$ (Dinas Kesehatan DIY, 2018). 
Anemia can cause lethargy, fatigue, and low of concentration which have impacts on learning achievement. In addition, low body immunity is susceptible to disease. Impact of anemia is not only short term but also longterm. If the incidence of anemia in adolescent is not handled immediately, it will persist into adulthood. Adolescents with anemia are at increased risk of morbidity and mortality rates of pregnant women. Maternal and infant health can be compromised. Therefore, it needs special attention to prepare healthy reproduction since teen ages (Rosmalina, 2010).

Iron is an essential component for the body because it plays a role in the process of red blood cell formation and metabolism. The amount of iron in the body is very little that is 35 grams. When the body lacks food intake, the body will disassemble the iron stores in the body to meet the requirement. If this happens, it will increase the risk of anemia in adolescents (Proverawati, 2011).

The research of (Astuti \& Trisna, 2016) stated that diet is associated with anemia. The results show that most adolescents have irregular eating habits such as going to school without having breakfast. This is due to the unavailability of food in the house. While in school, these teens prefer the lunch menu only with meatballs or noodles.

The Indonesian government policy in tackling the incidence of anemia is by implementing a program of iron tablet supplementation. The program of giving blood tablets in adolescents through school has reached $80.9 \%$. However, most adolescent $(98.6 \%)$ have not routinely consumed blood tablets. The government has targeted that adolescent should consume tablets up to 52 tablets (Kemenkes RI, 2018). Based on a preliminary study in Senior High School Muallimat Yogyakarta, of 10 students who suffered from anemia, $90 \%$ of them had never consumed $\mathrm{Fe}$ tablet regularly during menstruation. Therefore, this research was to find out the adolescents' characteristics with anemia in Senior High School Muallimat Yogyakarta.

\section{Method}

This study is descriptive analytic with cross-sectional approach, The population of this research were 425 students of class $X$ and the sampling used purposive sampling techniques, with inclusion and exclusion criteria which were students who had menstruation and experienced anemia proven by the results of hemoglobin measurement device. So there were total sample of 40 students, all of them with mild anemia category. The study was done in 2019 in Senior High School Muallimat Yogyakarta using the instrument of research table recaps. The data analysis of study used univariate analysis with frequency distribution calculation.

\section{Results And Discussion}

The study conducted with respondents of 40 adolescents who had experienced anemia found the characteristic features including age, age of menarche, cycle and length of menstruation as follows:

a. Characteristics of respondents in adolescents with anemia based on the age of respondents

Table 1 Characteristics of respondents adolescents with anemia in Senior High School Muallimat Yogyakarta

\begin{tabular}{|c|c|c|c|}
\hline No. & Characteristic & $\begin{array}{l}\text { Frequency } \\
(\mathbf{N})\end{array}$ & $\begin{array}{c}\text { Percentage } \\
(\%)\end{array}$ \\
\hline & Age & & \\
\hline 1. & Age 15 years & 13 & 32.5 \\
\hline 2. & Age 16 years & 22 & 55.0 \\
\hline 3. & Age 17 years & 3 & 7.5 \\
\hline 4. & $\begin{array}{l}\text { Age } 18 \text { years } \\
\text { age of menarche }\end{array}$ & 2 & 5.0 \\
\hline 1. & Age 10 years & 3 & 7.5 \\
\hline 2. & Age 11 years & 6 & 15.0 \\
\hline 3. & Age 12 years & 12 & 30.0 \\
\hline 4. & Age 13 years & 11 & 27.5 \\
\hline 5. & Age 14 years & 7 & 17.5 \\
\hline 6. & $\begin{array}{l}\text { Age } 15 \text { years } \\
\text { Menstrual cycle }\end{array}$ & 1 & 2.5 \\
\hline 1. & 1 month & 35 & 87.5 \\
\hline 2. & 1 month 2 times & 22 & 7.5 \\
\hline 3. & 2 months & 3 & 5.0 \\
\hline $\begin{array}{l}1 . \\
2 .\end{array}$ & $\begin{array}{l}\text { Old Mesntruasi } \\
\text { 3-7 days } \\
>7 \text { days }\end{array}$ & $\begin{array}{l}29 \\
11\end{array}$ & $\begin{array}{l}72.5 \\
27.5\end{array}$ \\
\hline $\begin{array}{l}1 . \\
2 . \\
3 .\end{array}$ & $\begin{array}{l}\text { Anaemia } \\
\text { Mild anemia } \\
\text { Moderate anemia } \\
\text { Severe anemia } \\
\text { Total }\end{array}$ & $\begin{array}{r}40 \\
0 \\
0 \\
40 \\
\end{array}$ & $\begin{array}{r}100 \\
0 \\
0 \\
100\end{array}$ \\
\hline
\end{tabular}

The data show the majority of respondents was 16 years $(55 \%)$, the results of this study indicated that adolescents were very susceptible to anemia. This is in line with the data of 
Kemenkes RI (2018), that the age of the most anemic range $15-24$ years is $86.4 \%$.

Adolescents is a dynamic period of growth and development. This period is a stage of transition from childhood to adulthood characterized by the development of physical, mental, emotional, and social (Dhamayanti, 2013). According to Santrock (2010), adolescence is considered as a period of storm and stress (Storm and Stress), because during adolescence, a person has a desire to freely determine his / her choice.

The study results of Sari (2019) show that most teens who were less knowledgeable suffered from anemia. So there is a correlation between knowledge and anemia of adolescents. Teens with poor knowledge have $7 \mathrm{x}$ greater risk of anemic than those with good knowledge.

This is in line with the policy of the Indonesian government through direct health promotion strategies to schools which aim to increase knowledge of adolescents about anemia. Adolescents with good knowledge will keep their diet and nutritional intake.

b. Characteristics of respondents in adolescents with anemia by age of menarche

Based on research data, a majority of respondents first got menstruation when they were 12 years old, meaning that adolescents who were anemic in Senior High School Muallimat were included in the category of ideal menarche age. This is in line with Proverawati \& Misaroh (2009) who argued that menarche menstruation was first experienced by women during puberty. Normal menarche age is $12-14$ years, while when it is before 12 years old, it is categorized early menarche.

In this study, all respondents were anemic, but the age of menarche ranged from age 10 - 15 years. In accordance with the classification by age of menarche by Proverawati \& Misaroh (2009), it was concluded that there were 9 respondents who experienced early menarche, and 31 respondents who had a normal age of menarche. This is in line with research Dumilah \& Sumarmi (2017) which stated that the age of menarche is not associated with anemia. However, anemia can affect the age of menarche pullback for 1.5 to 2 years and can disrupt the body's immunity. To prevent teens from anemia is by keeping the diet and nutrition, such as the consumption of fruits and vegetables containing iron. c. Characteristics of respondents in adolescents with anemia based on the menstrual cycle

On this research, as many as 40 respondents already menstruate regularly. In line with Proverawati (2011), anemia often affects adolescents due to menstruation, stress state, bleeding, impaired iron absorption, deworming, nutrition, syndrome mal absorption of iron and a meal delay. Stress can be avoided by spending time with positive and fun activities, such as try up for school sports.

The result found that the majority of respondents (a total of 35 respondents : 87.5\%). had regular menstrual cycle every month. According to Djaeni (2012), menstruation is regular discharge of endometrial epithelial tissue caused by changes in the hormonal balance of the female reproductive. Adolescents begin menarche and menses accompanied by the disposal of a number of red blood cells.

Kristianti et al. (2014) stated that menstrual cycles is associated with the incidence of anemia in adolescents in SMAN 1 Imogiri, Bantul. Anemia in adolescence can lead to disruption of the menstrual cycle, as they relate to changes in steroid hormone levels which are the main factors of the menstrual cycle. One of irregularities of menstrual cycle is caused by iron deficiency in the body that leads to low hemoglobin levels. In adolescents who are anemic, the supply of oxygen to the whole body will be reduced, which will affect the hormone Follicle stimulating hormone and luteinizing hormone produced by the hypothalamus.

Consumption of blood tableting regularly during menstruation can help maintain hemoglobin levels in order not to go lower. Iron tablet can be taken one time a day, at night before bed, using water.

d. Characteristics of respondents in adolescents with anemia by the length of periods

The research data show that the majority of adolescents in Senior High School Muallimat Yogyakarta with the length of menstrual period for 3-7 days were as many as 29 respondents (72.5\%). According to Bobak (2014) the length of menstruation is the time of menstrual bleeding process occurring in women. The time of expenditure menstrual blood is diverse -generally lasts for 4 to 6 days.

According to research of Febrianti et al. (2013), when a woman's menstrual period is more than 7 days, it can be one of the signs or symptoms of bleeding menorrhagia longer than 
the normal time. Menorrhagia is related to hormonal imbalance or dysfunction of the female reproductive organs. According to Bobak (2014), menstrual blood expenditure consists of parts decay endometrium layer mixed with blood and the uncertain amount.

Based on data from the study, there were 11 respondents $(27.5 \%)$ who experienced menses more than 7 days. This matter is in line with research of Basith et al. (2017) which states that the length of menstrual cycle is associated with anemia. Abnormalities of menstrual cycle length can increase the risk of anemia, due to the amount of blood loss which is more than the normal one, and resulted in low levels of hemoglobin in the blood. Similarly, research of Jaelani et al. (2017) also stated that there are links between long periods with the incidence of anemia. Adolescents who experience long periods of more than the normal time can be at risk of anemia. Exercise and diet can prevent anemia.in adolescents.

Limited research is the sample amount of only 40 respondents.

\section{Conclusions and Suggestions}

The characteristic features of adolescents in Senior High School Muallimat Yogyakarta, shows that the majority of respondents is aged 16 years of the 22 respondents (63.0\%). Most respondents experienced menarche at age 12 years are as many as 12 respondents (30.0\%). Adolescents in Senior High School Muallimat Yogyakarta having experienced the majority of the regular menstrual cycle are 35 respondents $(87.5 \%)$. In addition, long periods in adolescents in Senior High School Muallimat Yogyakarta show that the majority of respondents in the normal category (3-7 days) are as many as 29 students $(72.5 \%)$. The results show characteristic features in adolescent at Senior High School Muallimat Yogyakarta, mostly within the normal ranges, according to the age of menarche, menstrual cycles and the length of menstruation, but still anemic.

Senior High School Muallimat Yogyakarta is expected to do the prevention and control of anemia in cooperation with local district health facilities for providing information about anemia to adolescents. In addition, the need for assistance to young women to regularly take iron tablets each time period, as well as consume fruits and vegetables containing vitamin B12 is very crucial.

\section{Acknowledgements}

Thank to God the Almighty, the research team, the 'Aisyiyah University Yogyakarta as funders and Senior High School Muallimat Yogyakarta that has been willing to be a place of research.

\section{Reference}

Astuti RD dan Trisna E. (2016).Faktor-Faktor yang Berhubungan dengan Kejadian Anemia pada Remaja Putri Wilayah Lampung Timur. Jurnal Keperawatan 12(2): 243-251

Budianto. (2009). Dasar-dasar Ilmu Gizi.Malang: UMM Press.

Basith, A.. Agustina, R., Diani, N. (2017). Faktor-Faktor yang Berhubungan dengan Kejadian Anemia pada Remaja Putri.Jurnal Dunia Keperawatan 5(1): 1-10 https://ppjp.ulm.ac.id/journal/index.p $\mathrm{hp} / \mathrm{JDK} /$ article/view/3634.

Bobak, LJ. (2014). Buku Ajar Keperawatan Maternitas. Jakarta: Penerbit Buku Kedokteran EGC.

Dhamayanti, M. (2013). IDAI Indonesia Pediatric Society. Overview Adolescent Health Problems And Services. http://www.idai.or.id/artikel/seputarkesehatan-anak/overview-adolescenthealth-problems-and-services.

Dinas Kesehatan Republik Daerah Istimewa Yogyakarta. (2018). Evaluasi Anemia Pada Remaja di Daerah Istimewa Yogyakarta. https://dinkes.jogjaprov.go.id/berita/d etail/anemia-dan-risiko-kek-padaremaja-putri-di-diy--anemia-dan-risikokek-pada-remaja-putri-di-diy-

Djaeni, A. (2012). Ilmu Gizi untuk Mahasiswa Profesi Di Indonesia.Jakarta: Dian Rakyat.

Dumilah dan Sumarni. (2017). Hubungan Kejadian Anemia Dengan Prestasi Belajar Siswi Di SMP Unggulan Bina Insani. Amerta Nutr (2017) 331-340 DOI:

Febrianti, dkk.(2013). Lama Haid dan Kejadian Anemia Pada Remaja Putri.Jurnal Kesehatan Reproduksi, 4(1): 11-15.

Hapzah dan Yulita R. (2012). Hubungan Tingkat Pengetahuan dan Status Gizi Terhadap Kejadian Anemia Remaja Putri Pada Siswi Kelas III di SMAN 1 Tinambung Kabupaten Polewali Mandar.Jurnal Media Gizi Pangan 13(1): 20-25 
Jaelani, dkk.(2017). Faktor Resiko yang Berhubungan dengan Anemia Remaja Putri. Jurnal Kesehatan Politeknik Kesehatan Kementrian Kesehatan Tanjung Karang 8 (3): 358-368.

Kemenkes RI. (2018). Hasil Utama RISKESDAS 2018.

dalam

http:/ / farmasi.unpad.ac.id/wpcontent/uploads/hasil-riskesdas2018.pdf.

Kirana, D. (2011). Hubungan Asupan Zat Gizi dan Pola Menstruasi dengan Kejadian anemia pada Remaja Putri di SMA N 2 Semarang. Artikel Penelitian. Semarang: Fakultas Kedokteran Universitas Diponegoro

http://eprints.undip.ac.id/32594/1/395

_Dian_Purwitaningtyas_Kirana_G2C007 022.pdf

Kristianti, S., Wibowo, TA., Winarsih. (2014). Hubungan anemia dengan siklus menstruasi pada remaja putri di SMA
Negeri 1 Imogiri, Bantul, Yogyakarta. Jurnal Studi Pemuda 3(1): 33-38.

Proverawati, A. (2011). Gizi untuk Kebidanan. Yogyakarta: Yulia Medika.

Proverawati dan Misaroh. (2009). Menarche. Yogyakarta: Medical Book.

Rosmalina. 2010. Prinsip Dasar Ilmu Gizi. Jakarta: Gramedia Pustaka.

Santrock. 2010. Dinamika Perkembangan Anak dan Remaja. Jakarta: Erlangga.

Sari, NW. (2019).Faktor Kejadian Anemia Pada Remaja Putri di MTSN Talawi Kota Sawahlunto. Jurnal Menara Ilmu Universitas Muhammadiyah Sumatera $\begin{array}{llll}\text { Barat } & 13 & \text { (4): } & \text { 70-76. }\end{array}$ https://www.jurnal.umsb.ac.id/index. $\mathrm{php} / \mathrm{menarailmu/article/view/1310/1}$ 148

Yuni, NH. (2015). Kelainan Darah. Yogyakarta: Nuha Medika. 